\title{
Growth rates in children recovering from protein-calorie malnutrition
}

\author{
BY ANN ASHWORTH \\ Medical Research Council, Tropical Metabolism Research Unit, \\ University of the West Indies, Famaica
}

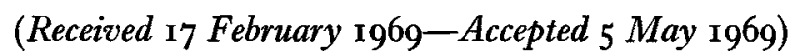

\begin{abstract}
r. Compensatory, or 'catch-up', growth in eight malnourished children has been studied in relation to food intake, efficiency of food utilization and changes in body composition.

2. During recovery, growth rates were fifteen times as fast as those of normal children of similar age, and five times as fast as those of normal children of a similar height or weight.

3. Rapid growth was associated with a high food intake.

4. When the expected weight for height was reached food intakes fell abruptly by $30 \%$ and growth rates dropped to a level comparable with those of normal children of that height and weight.

5. Food conversion figures suggest an over-all increase in the efficiency of food utilization during rapid growth.

6. The percentage body fat increased, once the expected weight for height was reached.

7. Differences in the rates of weight gain from those predicted by the Miller-Payne equation were difficult to interpret: problems associated with the equation are discussed.
\end{abstract}

Reports from Jordan, Chile and South Africa indicate that infants with proteincalorie malnutrition sometimes recover extremely slowly (McLaren, 1966; Mönckeberg, 1968 ; Pretorius \& Novis, 1965 ). However, in Jamaica we find that rapid recovery rates can be achieved if the calorie intake is sufficiently high (Ashworth, Bell, James \& Waterlow, 1968); in fact, the majority of our recovering infants grow at rates which are four to six times as great as those of normal infants of a similar weight or height, and the rates are even more strikingly different when compared with normal infants of a similar age.

In our ward children are considered to have recovered from malnutrition when they reach their expected weight for height, and are usually then sent home. Sometimes, however, they remain with us beyond this point, and we have repeatedly noticed that the growth rates of these children fall off dramatically once the expected weight for height has been reached. We use as our standards the 5oth percentile figures for American children (Nelson, 1959), from which the expected weight for height can be calculated by plotting a graph of median weight against median height.

Recently we have been trying to determine the reason for this change in growth rate. Three possibilities so far have been studied: (I) whether there are any changes in food intake; (2) whether protein and calories are being utilized more efficiently during the period of rapid growth; (3) whether there are differences in the composition of the tissue being laid down. 
EXPERIMENTAL

Subjects. Eight malnourished children have been investigated. There were six males and two females, and their ages on admission ranged from ro months to 3 years. All were severely malnourished and their body-weights, expressed as a percentage of the expected weight for height, ranged from 53 to $70 \%$. Details of the individual children on admission are given in Table 1 . The children were studied $(a)$ when they were growing very rapidly and $(b)$ after they had reached their expected weight for height and were fully recovered.

Table r. Clinical details of the children on admission

\begin{tabular}{|c|c|c|c|c|c|c|c|}
\hline Child & Sex & $\begin{array}{c}\text { Age } \\
\text { (months) }\end{array}$ & $\begin{array}{l}\text { Height } \\
\text { (cm) }\end{array}$ & $\begin{array}{c}\text { Weight } \\
\text { (kg) }\end{array}$ & $\begin{array}{l}\text { Expected } \\
\text { weight for } \\
\text { height (kg) }\end{array}$ & $\begin{array}{l}\text { Wt as \% of } \\
\text { expected } \\
\text { wt for ht }\end{array}$ & $\begin{array}{c}\text { Clinical } \\
\text { diagnosis }\end{array}$ \\
\hline E. E. & $\mathbf{M}$ & I3 & $64 \cdot 5$ & 3.94 & $6 \cdot 95$ & 57 & Marasmus \\
\hline D. P. & $\mathbf{M}$ & IO & $65 \cdot 2$ & $4 \cdot 53$ & $7 \cdot 17$ & 63 & $\begin{array}{l}\text { Marasmic- } \\
\text { kwashiorkor }\end{array}$ \\
\hline D. N. & $\mathbf{M}$ & 16 & 70.5 & 4.71 & $8 \cdot 87$ & 53 & Marasmus \\
\hline V. M. & $\mathrm{F}$ & 18 & 73.5 & $6 \cdot 78$ & $9 \cdot 68$ & 70 & $\begin{array}{l}\text { Marasmic- } \\
\text { kwashiorkor }\end{array}$ \\
\hline A. L. & $\mathbf{M}$ & 36 & $74 \cdot 5$ & $6 \cdot 36$ & 9.92 & 64 & $\begin{array}{l}\text { Marasmic- } \\
\text { kwashiorkor }\end{array}$ \\
\hline M. G. & $\mathbf{F}$ & 13 & $63 \cdot 0$ & $3 \cdot 68$ & $6 \cdot 47$ & 57 & Marasmus \\
\hline An. $\mathrm{H}$. & $\mathbf{M}$ & 14 & 68.0 & $5 \cdot 43$ & $8 \cdot 10$ & 67 & $\begin{array}{l}\text { Marasmic- } \\
\text { kwashiorkor }\end{array}$ \\
\hline \multirow[t]{2}{*}{ Al. H. } & $\mathbf{M}$ & 14 & $67 \cdot 5$ & $5 \cdot 25$ & 7.93 & 66 & $\begin{array}{l}\text { Marasmic- } \\
\text { kwashiorkor }\end{array}$ \\
\hline & & an $\quad 16.5$ & $68 \cdot 3$ & $5 \cdot 08$ & $8 \cdot 14$ & 62 & \\
\hline
\end{tabular}

Table 2. Composition per l. of the milk preparation

Dried full-cream milk*
Arachis oil
Calories
Protein

$190 \mathrm{~g}$
$60 \mathrm{~g}$
$135 \circ \mathrm{kcal}$
$31 \mathrm{~g}$

* A proprietary preparation which incorporates maize starch, dextrin-maltose and sucrose; total carbohydrate $57 \%$, fat $17 \%$, protein $16.5 \%$.

Dietary regime and growth rates. The treatment of the children on admission to hospital was as described by Garrow, Picou \& Waterlow ( 1962 ), and consisted essentially of the control of infection and the introduction of graduated feeds with potassium, iron and vitamin supplements. As soon as the children were feeding well and diarrhoea, vomiting and other disturbances had been controlled, they were fed a milk preparation, the composition of which is given in Table 2. The volume of feed was adjusted to provide $165 \mathrm{kcal}$ and $3.8 \mathrm{~g}$ protein per $\mathrm{kg}$ body-weight per day. As the children grew the volume of milk was increased each week so that they were offered the same quantity of calories and protein per $\mathrm{kg}$ throughout the study. All dietary intakes were measured accurately. Children who had reached their expected weight for height had to be 
coaxed and encouraged to take the whole feed and, if they refused, the milk was put aside and then offered again a little later. A special note was made of any milk still not consumed.

Each child was weighed daily. Growth rates were measured over periods of 20 days by fitting a line by the method of least squares, and were determined $(a)$ during the period of rapid growth and $(b)$ after the expected weight for height had been reached.

Efficiency of food utilization. Efficiencies of protein utilization were to have been compared in the two periods by the nitrogen balance method, but problems were encountered with the children who had reached their expected weight for height since they would not eat as much as before. For the comparison to be valid, it is necessary to give the same intake per $\mathrm{kg}$, and so it was decided that for the duration of the balance the children were to be given by nasogastric tube any milk not consumed voluntarily. This was not the solution since, of the first two children studied, one persistently vomited when forcibly fed, and the other ran a high fever on every occasion. Nitrogen balances were therefore discontinued. As an alternative it was decided to compare the observed rates of weight gain during the period of rapid growth and after the expected weight for height had been reached with those predicted by the equation of Miller \& Payne (1963):

$$
\text { weight gain }=37\left(0.4 S C P-0.0076 S C P^{2}-250\right),
$$

where $S=$ protein score expressed as a fraction, $C=$ calorie intake (kcal $/ \mathrm{kg}^{0 \cdot 73}$ per day) and $P=$ protein calories expressed as a percentage of total calories. Four $48 \mathrm{~h}$ collections of urine and faeces were obtained from two of the children and the urine was analysed for nitrogen by the micro-Kjeldahl method. The calorie content of the urine was taken as $4.8 \mathrm{kcal} / \mathrm{g}$ nitrogen (Southgate \& Barrett, 1966) and the calorie content of the faeces was measured directly with a ballistic bomb calorimeter. The mean calorie content of the urine and faeces represented $8 \%$ of the intake, and values for metabolizable energy used in the equation were therefore taken as being $92 \%$ of the intake. The protein score of the diet was taken as 0.78 (Orr \& Watt, 1957).

Body composition. In order to determine whether there were any changes in the composition of the tissue being laid down, serial measurements were made of total body potassium, by counting the natural isotope ${ }^{40} \mathrm{~K}$ in a whole body liquid scintillation counter (Garrow, 1965). Lean body mass in $\mathrm{kg}$ was calculated as equal to

$$
\frac{\text { total body potassium (m-equiv.) }}{\text { potassium concentration in lean tissue (m-equiv. } / \mathrm{kg} \text { ) }} \text {, }
$$

the potassium concentration in lean tissue being derived by interpolation from measurements made in the newborn (Widdowson \& Spray, 195 I), and in children at I year (Garrow, Fletcher \& Halliday, 1965) and at 4.5 years (Widdowson, McCance \& Spray, $195 \mathrm{I}$ ). The equation for lean body mass is only valid if there is no excess body water. Total body water is increased in malnutrition even in non-oedematous subjects (Smith, I960), but the excess water usually disappears within $3^{-6}$ weeks after admission (Halliday, 1966). Consequently, no estimates of lean body mass during the first 6 weeks have been included. 
Body fat was taken as the difference between lean body mass and body-weight, and was expressed as a percentage of the body-weight.

\section{RESULTS}

The patterns of growth are shown in Fig. I. There was a definite falling off in growth rate in six children coincident with their reaching their expected weight for height. Two children, A. L. and M. G., continued to gain weight, although less rapidly
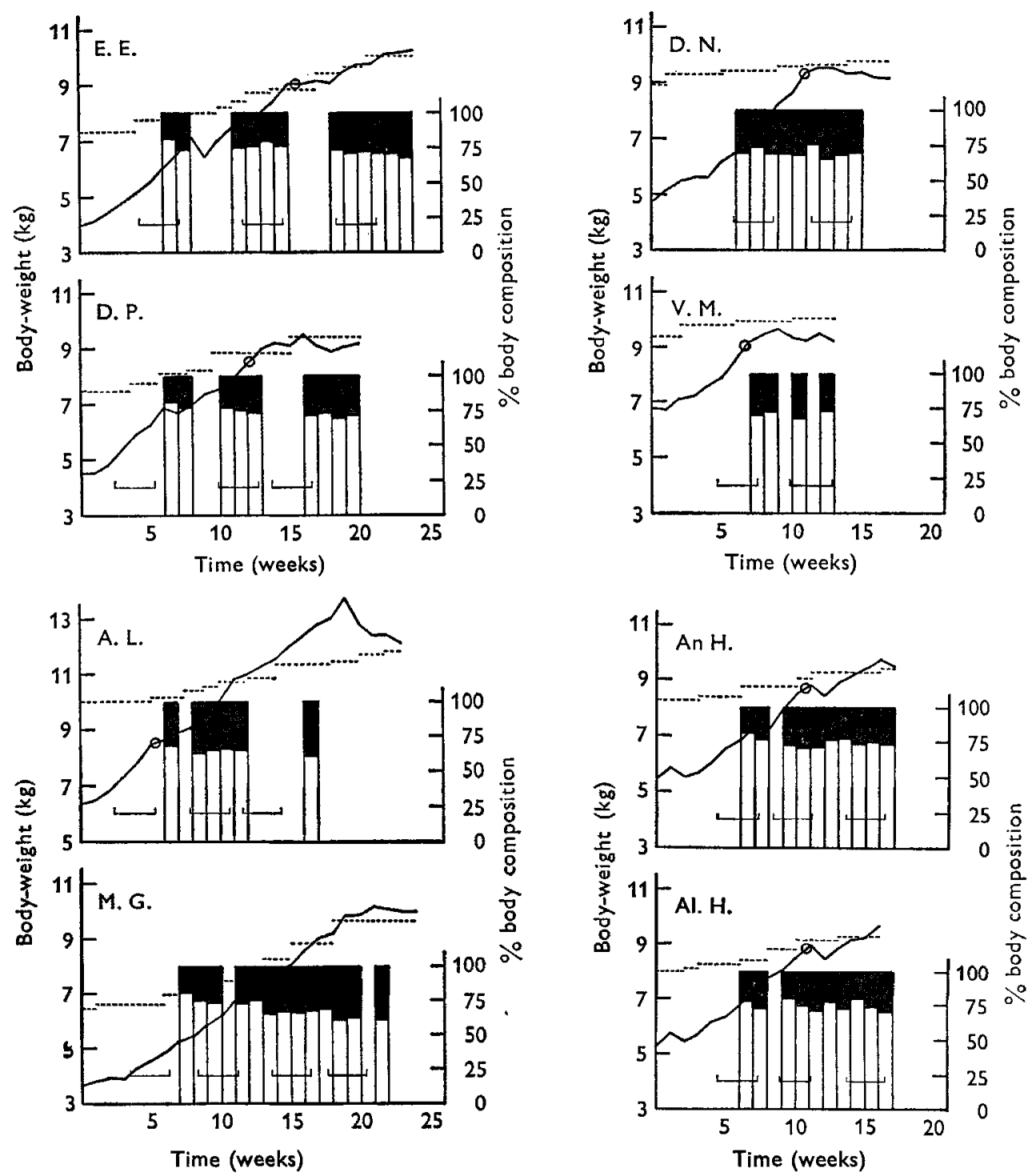

Fig. I. Patterns of growth and the changes in body composition in children during and after recovery from malnutrition. - ..., the expected weight for height; $O$, the first occasion on which food was refused for 3 consecutive days; $L$, the periods during which growth rates and food intakes were measured; $\mathbf{\square}, \%$ body fat; $\square$, \% lean body mass. 
than before, and overshot their expected weight for height. Later A. L. lost weight and M. G. rapidly increased in height so that their weight also reached a plateau at the expected weight for height.

Growth rates. Growth rates were measured in all the children within 8 weeks of admission to hospital (growing, period $\mathbf{I}$ ); further measurements were made in six of the children before they reached their expected weight for height (growing, period 2). All children were measured again, when they had reached their expected weight for height (after recovery). Table 3 shows that the gains in body-weight were similar, in absolute terms, in periods $I$ and 2, and were significantly greater than the gain in weight after recovery $(P<0.02)$. The growth rate expressed per $\mathrm{kg}$ body-weight was greater in period I than in period $2(P<0.0 I)$. The mean growth rate after full recovery again was significantly lower than in either period I $(P<0.00 \mathrm{I})$ or period $2(P<0.005)$.

Table 3. Observed growth rates of the children during the periods (a) 6-8 weeks after admission to hospital (growing, period $\mathrm{r}$ ), (b) from 8 weeks after admission to time when expected weight for height was reached (growing, period 2) and (c) after expected weight jor height was reached (after recovery), and the theoretical values calculated from the Miller $\wp^{\circ}$ Payne (1963) equation

\begin{tabular}{|c|c|c|c|c|c|c|c|c|c|}
\hline & \multicolumn{3}{|c|}{ Growing, period I } & \multicolumn{3}{|c|}{ Growing, period 2} & \multicolumn{3}{|c|}{ After recovery } \\
\hline & \multicolumn{2}{|c|}{ Observed } & \multirow{2}{*}{$\begin{array}{l}\text { Theo- } \\
\text { retical } \\
\text { g/kg day }\end{array}$} & \multicolumn{2}{|c|}{ Observed } & \multirow{2}{*}{$\begin{array}{l}\text { Theo- } \\
\text { retical } \\
\text { g/kg day }\end{array}$} & \multicolumn{2}{|c|}{ Observed } & \multirow{2}{*}{$\begin{array}{l}\text { Theo- } \\
\text { retical } \\
\text { g/kg day }\end{array}$} \\
\hline & g/day & $\mathrm{g} / \mathrm{kg}$ day & & g/day & $\mathrm{g} / \mathrm{kg}$ day & & g/day & g/kg day & \\
\hline E. E. & $70 \cdot 3$ & $12 \cdot 04$ & $8 \cdot 43$ & $74 \cdot 8$ & $9 \cdot 35$ & 9.05 & $28 \cdot 8$ & $2 \cdot 99$ & $4 \cdot 95$ \\
\hline D. P. & $62 \cdot 6$ & 10.98 & 8.67 & $66 \cdot 3$ & $8 \cdot 20$ & 8.69 & $-1 \cdot 6$ & -0.17 & $\begin{array}{l}+93 \\
5.59\end{array}$ \\
\hline D. N. & $78 \cdot 6$ & 10.94 & $8 \cdot 48$ & - & - & - & $-8 \cdot 7$ & -0.91 & $4 \cdot 85$ \\
\hline V. M. & $82 \cdot 8$ & $9 \cdot 65$ & $8 \cdot 35$ & - & 一 & - & $3 \cdot 6$ & 0.39 & 3.84 \\
\hline A. L. & 79.4 & 10.32 & $8 \cdot 33$ & $67 \cdot 8$ & $6 \cdot 87$ & 8.09 & $3^{8 \cdot 1}$ & $3 \cdot 3^{6}$ & $5 \cdot 82$ \\
\hline M. G. & $38 \cdot 3$ & $8 \cdot 37$ & 8.00 & $54 \cdot 0^{*}$ & $7 \cdot 72^{*}$ & $7 \cdot 59^{*}$ & 50.9 & $5 \cdot 21$ & $5 \cdot 28$ \\
\hline An. $\mathrm{H}$. & $57 \cdot 8$ & $8 \cdot 54$ & $8 \cdot 73$ & 65.9 & $7 \cdot 95$ & $7 \cdot 83$ & $3 x \cdot 2$ & $3 \cdot 33$ & $5 \cdot 40$ \\
\hline Al. $\mathrm{H}$. & $62 \cdot 7$ & $9 \cdot 36$ & $8 \cdot 8 I$ & $57 \cdot 2$ & $6 \cdot 68$ & $7 \cdot 50$ & $29 \cdot 8$ & $3 \cdot 21$ & $5 \cdot 78$ \\
\hline Mean & $66 \cdot 6$ & 10.02 & $8 \cdot 47$ & $64 \cdot 3$ & $7 \cdot 79$ & $8 \cdot 12$ & $21 \cdot 5$ & $2 \cdot 18$ & $5 \cdot 19$ \\
\hline
\end{tabular}

Food intakes. The children took their feeds very readily during period $\mathrm{I}$ and also for the greater part of period 2. Six children abruptly started refusing feeds at about the time when they reached their expected weight for height, and the rate of weight gain then fell off. The two exceptions, A. L. and M. G., started refusing their feeds somewhat earlier and reached their plateau weight much later than the other children. The point at which the children first refused to eat for 3 consecutive days is marked in Fig. $\mathrm{r}$.

The reduction in food intake, after the children had reached their expected weight for height, was substantial and surprisingly uniform (Table 4). The mean calorie intake dropped to $1 \mathrm{I} 6 \mathrm{kcal} / \mathrm{kg}$ per day compared with $\mathrm{I} 60 \mathrm{kcal} / \mathrm{kg}$ per day in period I, and $152 \mathrm{kcal} / \mathrm{kg}$ per day in period $2(P<0 \cdot 00 \mathrm{I}$ in each instance).

Efficiency of food utilization. A comparison of the actual growth rates with the theoretical values calculated from the Miller-Payne equation is given in Table 3 . 
During period $\mathrm{I}$ the growth rates were higher than the theoretical values in all but one child, An. H. The mean observed gain was significantly greater than the expected gain $(P<0 \cdot 001)$. In period 2 there was no significant difference, but in the final period, when the children had reached their expected weight for height, the position was reversed and the growth rates were consistently lower than the theoretical values $(P<0.001)$.

Table 4. Mean food intakes of the children (a) 6-8 weeks after admission to hospital (growing, period I), (b) from 8 weeks after admission to time when expected weight for height was reached (growing, period 2), and (c) after expected weight for height was reached (after recovery)

\begin{tabular}{|c|c|c|c|c|c|c|c|c|c|}
\hline \multirow[b]{2}{*}{ Child } & \multicolumn{3}{|c|}{ Growing, period I } & \multicolumn{3}{|c|}{ Growing, period 2} & \multicolumn{3}{|c|}{ After recovery } \\
\hline & $\begin{array}{c}\text { Calories } \\
\text { (kcal/kg } \\
\text { day) }\end{array}$ & $\begin{array}{c}\text { Protein } \\
\text { (g/kg day) }\end{array}$ & $\begin{array}{l}\text { Feed } \\
\text { refused } \\
(\%)\end{array}$ & $\begin{array}{c}\text { Calories } \\
\text { (kcal/kg } \\
\text { day) }\end{array}$ & $\begin{array}{l}\text { Protein } \\
\text { (g/kg day) }\end{array}$ & $\begin{array}{c}\text { Feed } \\
\text { refused } \\
(\%)\end{array}$ & $\begin{array}{c}\text { Calories } \\
\text { (kcal/kg } \\
\text { day) }\end{array}$ & $\begin{array}{l}\text { Protein } \\
\text { (g/kg day) }\end{array}$ & $\begin{array}{l}\text { Feed } \\
\text { refused } \\
(\%)\end{array}$ \\
\hline E. E. & 162 & 3.73 & o & $r 63$ & $3 \cdot 75$ & o & II4 & $2 \cdot 62$ & 26 \\
\hline D. P. & 165 & $3 \cdot 79$ & ○ & I59 & 3.66 & $\mathbf{I}$ & 121 & $2 \cdot 77$ & 25 \\
\hline D. N. & 159 & $3 \cdot 64$ & 0 & - & - & 一 & 113 & $2 \cdot 59$ & 3I \\
\hline V. M. & 155 & 3.55 & 3 & - & 一 & $\longrightarrow$ & 102 & $2 \cdot 34$ & $3^{8}$ \\
\hline A. L. & I 56 & $3 \cdot 58$ & $\mathbf{r}$ & 150 & $3 \cdot 44$ & 8 & I2I & $2 \cdot 78$ & 25 \\
\hline M. G. & $16 x$ & $3 \cdot 71$ & $\circ$ & $149^{*}$ & $3.42^{*}$ & $5^{*}$ & 117 & $2 \cdot 70$ & 23 \\
\hline An. $\mathrm{H}$. & 162 & $3 \cdot 73$ & $\circ$ & I 49 & $3 \cdot 43$ & 3 & 120 & $2 \cdot 75$ & 24 \\
\hline Al. $\mathrm{H}$. & 164 & 3.76 & o & 145 & 3.33 & 4 & 124 & $2 \cdot 84$ & 23 \\
\hline Mean & 160 & 3.69 & 0.5 & 152 & 3.50 & 3 & 116 & $2 \cdot 67$ & 27 \\
\hline
\end{tabular}

Table 5. Calorie intake of the children above basal (kcal/g weight gain) (a) 6-8 weeks after admission to hospital (growing, period $\mathrm{I}$ ), (b) from 8 weeks after admission to time when expected weight for height was reached (growing, period 2) and (c) after expected weight for height was reached (after recovery)

\begin{tabular}{|c|c|c|c|}
\hline Child & Growing, period $\mathbf{I}$ & Growing, period 2 & After recovery \\
\hline E. E. & $7 \cdot 1$ & $9 \cdot 2$ & $17 \cdot 4$ \\
\hline D. P. & $8 \cdot 8$ & II'Z & \\
\hline D. N. & $8 \cdot 7$ & 一 & \\
\hline V. M. & $9 \cdot 5$ & - & $108 \cdot 0$ \\
\hline A. L. & $8 \cdot 8$ & $12 \cdot 3$ & $20 \cdot 4$ \\
\hline M. G. & $12 \cdot 3$ & II.9* & II:9 \\
\hline An. H. & $11 \cdot 9$ & $x I \cdot 2$ & $17 \cdot 7$ \\
\hline Al. H. & 9.7 & II.0 & 19.6 \\
\hline & Mean 9.6 & $I I \cdot I$ & $32 \cdot 5$ \\
\hline
\end{tabular}

A measure of the efficiency with which calories are utilized for growth is the calorie intake above basal per $\mathrm{g}$ weight gain. The values obtained are shown in Table 5 . The basal metabolic rate (BMR) was measured $4 \mathrm{~h}$ after the last feed while the child was asleep in a ventilated hood. The calorie intake required for unit gain was significantly less in period $I$ than in period $2(P<0.05)$. There was greater individual 
variation among the children after recovery, but in all children the calorie intake per $\mathrm{g}$ weight gain was much greater than in either of the two growing periods.

Body composition. The relative proportions of lean body mass and fat are illustrated in Fig. $\mathrm{I}$. The percentage of fat after the expected weight for height had been reached was significantly higher than at earlier stages of recovery, as shown in Table 6 . The increase in fat from a mean of $25.2 \%$ at 6-8 weeks after admission to $27.4 \%$ in period 2 was not statistically significant. One can never be certain of the absolute correctness of any indirect measurement of body composition, but nevertheless it seems reasonable to assume that relative changes are real and that these results represent a true increase in body fat once the expected weight for height is reached. There is very little information about the normal fat content of healthy children, but Garrow et al. (1965) in their whole body analyses of four clinically well-nourished children aged 9-I4 months found fat contents ranging from $\mathrm{I} 8 \cdot 4$ to $25.5 \%$, whilst Widdowson et al. (r $95 \mathrm{I}$ ) found the fat content of a $4 \cdot 5$-year-old child to be $22.7 \%$. During the period of rapid growth the percentage body fat was of the same order in most children.

Table 6. Mean body fat content (\%) of the children (a) 6-8 weeks after admission to hospital (growing, period I), (b) from 8 weeks after admission to time when expected weight for height was reached (growing, period 2), and (c) after expected weight for height was reached (after recovery)

\begin{tabular}{|c|c|c|c|}
\hline Child & Growing, period I & Growing, period 2 & After recovery \\
\hline \multirow{9}{*}{$\begin{array}{l}\text { E. E. } \\
\text { D. P. } \\
\text { D. N. } \\
\text { V. M. } \\
\text { A. L. } \\
\text { M. G. } \\
\text { An. H. } \\
\text { Al. H. }\end{array}$} & $22 \cdot 5$ & $23 \cdot 2$ & 30.0 \\
\hline & $2 I \cdot I$ & 25.5 & $28 \cdot 8$ \\
\hline & $29 \cdot 5$ & $31 \cdot 0$ & 30.4 \\
\hline & $28 \cdot 4$ & - & $29^{\circ} 0$ \\
\hline & $34 \cdot I$ & $34 \cdot 6$ & $36 \cdot 5$ \\
\hline & $22 \cdot 1$ & $29 \cdot 6$ & $35 \cdot 2$ \\
\hline & $20 \cdot 4$ & $25 \cdot 5$ & $25 \cdot 2$ \\
\hline & $23 \cdot 8$ & $22 \cdot 2$ & $25 \cdot 1$ \\
\hline & Mean 25.2 & $27 \cdot 4$ & $30 \cdot 0$ \\
\hline
\end{tabular}

\section{DISCUSSION}

The results of this study indicate that in children recovering from malnutrition the main factor which causes a fall-off in weight gain, once the expected weight for height has been reached, is a voluntary reduction in food intake. The rates of growth were indeed very rapid and exceeded those of normal children at any period from birth onwards. They were, on the average, fifteen times as fast as the normal growth rate of children of the same age, and five times as fast as that of younger children of a similar height or weight. The pattern of 'catch-up' or compensatory growth was similar to that occurring in children at the end of periods of anorexia, hypothyroidism, Cushing's syndrome or growth-hormone-responsive dwarfism (Tanner, 1963), and to that observed in rats at the end of periods of undernutrition (Widdowson $\&$ McCance, 1963). 
Tanner ( 1963 ) considers growth to be 'target-seeking' in the sense that if a child is deflected from its natural growth trajectory by malnutrition a restoring force develops as soon as food is supplied, so that the child catches up towards its original curve and when it gets there slows down to adjust its path on to the old trajectory once more. Most of the children in this study changed to a slower trajectory when they reached or neared their expected weight for height, and subsequently gained weight at rates which were similar to those of normal children of the same height. However, the growth rates were still three times as fast as those of normal children of the same age; it may be, therefore, that compensatory growth proceeds in two stages, the first being very rapid and continuing until the child is the correct weight for his height, the second, in which the child catches up to his correct weight for age, being slower and more prolonged. It is difficult to say whether malnourished children catch up completely, but a study from this Unit has shown that children 2-8 years after discharge were equal in height and weight to their siblings (Garrow \& Pike, 1967). This, however, does not exclude the possibility that the siblings also had been malnourished although not treated in hospital, and that neither group had reached its full growth potential.

One conclusion to be drawn from this study is that the regulation of food intake is of primary importance in determining the shift from one growth trajectory to another. The remarkable fact is just how sensitive a mechanism this can be, for six of the eight children started refusing their feed at a time virtually coincident with reaching their expected weight for height. The children consumed $\mathrm{I} 60 \mathrm{kcal} / \mathrm{kg}$ per day greedily during the period of rapid growth and would probably have taken more had it been offered. The reduction in food intake after the expected weight for height had been reached was very uniform. The calorie intake dropped to a mean of $116 \mathrm{kcal} / \mathrm{kg}$ per day, which is a little higher than the values of 106 and $103 \mathrm{kcal} / \mathrm{kg}$ per day reported by Rueda-Williamson \& Rose (1962) and by Beal (1953) for healthy American children of a similar age. It would be interesting to know whether a further reduction in food intake occurs when compensatory growth is complete.

The Miller-Payne ( 1963 ) equation was based on values obtained for young growing animals, and one of its aims was to assist developing countries in predicting the growth rates which would result from the feeding of given quantities of diets of known composition. It was directed towards the vulnerable groups of human populations and therefore it seemed appropriate to apply it to our results.

At first sight the results indicate that the efficiency of food utilization increases during the early period of rapid growth, and decreases after recovery. A drawback to the application of the Miller-Payne equation is that no provision is made for the calorie cost of activity. This is very relevant to the present study as the children were certainly more active after they had recovered. Moreover, on recovery there was a significant increase in the proportion of body fat, whereas the equation for predicting weight gain assumes that changes in body composition are small. It therefore seems likely that the lower efficiency after recovery is apparent rather than real, and results from changes in body composition and from neglecting differences in physical activity. 
Further difficulties arise when one considers that the equation which gives the best fit, and which was used in the present comparison (Miller \& Payne, 1963, equation 5), pre-supposes that the available nitrogen is the limiting factor controlling the rate of weight gain. It is doubtful if this is so in our patients, since previous work has shown that, over comparable ranges of intake, the rate of weight gain was closely related to the calorie intake, and very little to the protein intake (Ashworth et al. 1968). Furthermore, if a child receiving a daily protein intake of $3.8 \mathrm{~g}$ per $\mathrm{kg}$ is gaining ro $\mathrm{g}$ bodyweight per $\mathrm{kg}$ per day, containing $\mathrm{I} \cdot 7 \mathrm{~g}$ protein, and the maintenance requirement is $0.8 \mathrm{~g}$ per $\mathrm{kg}$ (Chan \& Waterlow, I966), then the net protein utilization (operative) of the protein consumed would be 66. Balance studies in this Unit (Chan \& Waterlow, 1966) have shown that the malnourished child can utilize cow's milk protein with almost 100\% efficiency when it is given at lower levels. Therefore it seems unlikely that in the subjects reported here the rate of growth was in fact limited by the protein intake.

If the calorie intake is considered to be the limiting factor, then, according to Miller $\&$ Payne (1963), a different equation should be applied: weight gain $=37(6 \cdot 8 C-725)$ (equation 6). Weight gains predicted from this equation are several times greater than those observed even in the most rapidly growing children, and it becomes difficult to draw conclusions based on these predicted values. Again, the reason for the lack of fit is probably that the equation makes no allowance for calories spent on physical activity.

The calorie expenditure of the growing child can be divided into three parts: basal metabolism, physical activity and growth. According to Miller \& Payne (1963) it requires 24 kcal to form I g protein, although McCracken ( 1968 ), quoting Kielanowski, gives a much lower figure. McCracken ( 1968 ) found a value of $15.9 \mathrm{kcal} / \mathrm{g}$ for the energy cost of fat formation. On this basis, it would require 8I kcal to form $10 \mathrm{~g}$ new tissue containing $\mathrm{I} \cdot 7 \mathrm{~g}$ protein and $2.5 \mathrm{~g}$ fat. If the BMR is taken as $53 \mathrm{kcal}$ per $\mathrm{kg}$ per day (the average found in this Unit), a child receiving $150 \mathrm{kcal}$ per $\mathrm{kg}$ per day would only have I $6 \mathrm{kcal}$ per $\mathrm{kg}$ remaining for activity. It seems therefore that the main reason why calories are limiting during rapid growth is the very high calorie cost of the formation of new tissue.

The food conversion values (Table 5) suggest that there was an increase in over-all efficiency during rapid growth, and particularly during the early period. This is in contrast to the findings in rats of Widdowson \& McCance (1963), and to those of Rutishauser \& McCance (1968) in malnourished children in Uganda. During the two periods of rapid growth the net efficiency, after allowing for the BMR, was about ro kcal/g weight gain. This is similar to results reported previously in a larger series of children (Ashworth et al. I968); the slope of the line relating weight gain to calorie intake gave a value of $12 \cdot 7 \mathrm{kcal} / \mathrm{g}$ weight gain.

After recovery, the efficiency appears to have been much less: if one excludes the three children D. P., D. N. and V. M. who were growing very slowly if at all at this time, the mean calorie intake per $\mathrm{g}$ gain was $17.4 \mathrm{kcal}$; this is comparable to the over-all estimate of $\mathrm{x} 6 \cdot 2 \mathrm{kcal}$ per $\mathrm{g}$ gain derived from values of $\mathrm{McCance} \&$ Widdowson (1964) for normal children whilst doubling their birth weight, who, although younger and lighter, would be growing at a similar rate. 
As yet we do not know what the stimulus to compensatory growth is, or how the body 'knows' when to stop growing. Tanner (1963) has put forward the hypothesis of a time tally mechanism controlled by the pituitary. In this regard it is well known that growth hormone will increase body-weight, increase nitrogen retention and favour the deposition of protein. Pimstone, Barbezat, Hansen \& Murray (1968) have shown that, although malnourished children have high levels of growth hormone on admission to hospital, the levels return to normal within 2-3 weeks of treatment. The period of rapid growth continues for much longer and it would appear, therefore, that growth hormone cannot play a key role in stimulating compensatory growth. However, these measurements were made after a $9 \mathrm{~h}$ fast and present work in our Unit seems to indicate that growth in these children does not occur evenly throughout the day but rather in spurts following meals (Ashworth, I969). If this is so, fasting may have obscured possible changes in release of growth hormone.

From the results of this study it seems that, whatever the factor is which stimulates growth, it must be closely associated with the regulation of appetite, for the food intakes of these children fell dramatically, and on the whole the changes were abrupt and coincident with their attaining the expected weight for height. Much attention has been directed towards the hypothalamus as the appetite-regulating centre (Kennedy, I96I); the hypothalamus is in close proximity to the pituitary but whether this physical association is related to the interdependence of appetite and compensatory growth is purely speculative. It is of interest to note that the two children who had reduced their intake and were being force-fed, counteracted by vomiting in one instance and fever in the other.

The conclusions drawn from this study are therefore: (I) that the change in growth rate on recovery is primarily due to a reduction in food intake; (2) that the controlling mechanism appears to be very sensitive; (3) that the over-all efficiency of food utilization is possibly increased during catch-up growth, and (4) that there is an increase in body fat once the expected weight for height has been reached.

I wish to acknowledge the help and guidance given by Professor J. C. Waterlow and Dr P. R. Payne.

\section{REFERENCES}

Ashworth, A. (1969). Nature, Lond. 223, 407.

Ashworth, A., Bell, R., James, W. P. T. \& Waterlow, J. C. (r968). Lancet ii, 600.

Beal, V. A. (1953). F. Nutr. 50, 223.

Chan, H. \& Waterlow, J. C. (1966). Br. F. Nutr. 20, 775.

Garrow, J. S. (1965). W. Indian med. F. 14, 73.

Garrow, J. S., Fletcher, K. \& Halliday, D. (1965). F. clin. Invest. 44, 417.

Garrow, J. S., Picou, D. \& Waterlow, J. C. (1962). W. Indian med.\%. 11, 2 I 7.

Garrow, J. S. \& Pike, M. C. (1967). Lancet i, r.

Halliday, D. (1966). Body composition in severe infantile protein malnutrition. $\mathrm{PhD}$. Thesis, University of London.

Kennedy, G. C. (196I). Proc. Nutr. Soc. 20, 58.

McCance, R. A. \& Widdowson, E. M. (I964). In Mammalian Protein Metabolism. Vol. 2, p. 227. [H. N. Munro and J. B. Allison, editors.] New York: Academic Press Inc.

McCracken, K. J. (I 968). Proc. Nutr. Soc. 27, 40A.

McLaren, D. S. (1966). Lancet ii, 485 .

Miller, D. S. \& Payne, P. R. (1963). F. theoret. Biol. 5, 398. 
Mönckeberg, F. (1968). In Calorie Deficiencies and Protein Deficiencies, p. 91. [R. A. McCance and E. M. Widdowson, editors.] London: J. A. Churchill Ltd.

Nelson, W. E. (r 959). Textbook of Pediatrics, 7 th ed. Philadelphia and London: W. B. Saunders Co.

Orr, M. L. \& Watt, B. K. (1957). Amino Acid Content of Foods. Home Economics Research Report no. 4. Washington: U.S. Department of Agriculture.

Pimstone, B. L., Barbezat, G., Hansen, J. D. L. \& Murray, P. (1968). Am. F. clin. Nutr. $21,482$.

Pretorius, P. J. \& Novis, H. (1965). S. Afr. med. F. 39, 237.

Rueda-Williamson, R. \& Rose, H. E. (1962). Pediatrics, Springfield 30, 639.

Rutishauser, I. H. E. \& McCance, R. A. (1968). Archs Dis. Childh. 43, 252.

Smith, R. (1960). Clin. Sci. 19, 275.

Southgate D. A. T. \& Barrett, I. M. (1966). Br. F. Nutr. 20, 363.

Tanner, J. M. (1963). Child Develop. 34, 817.

Widdowson, E. M. \& McCance, R. A. (I963). Proc. roy. Soc. B, 158, 329.

Widdowson, E. M., McCance, R. A. \& Spray, C. M. (195I). Clin. Sci. ro, 113.

Widdowson, E. M. \& Spray, C. M. (195 r). Archs Dis. Childh. 26, 205. 